\title{
Coral microatoll as geodetic tool in North Andaman and Little Andaman, India
}

\author{
S K Som*, Vijay Shivgotra and Ashim Saha \\ Earthquake Geology Division, Geological Survey of India, Eastern Region, DK-Block, \\ Sector-II, Salt Lake City, Kolkata 700 091, India. \\ *email:sksom@rediffmail.com
}

\begin{abstract}
Coral microatolls were examined from North Andaman and Little Andaman to understand the relative sea level change due to vertical tectonic deformation above the subduction interface. The highest level of survival of coral microatoll before the 26 December, 2004 earthquake at eastern coast of North Andaman has been determined by Global Ocean Tide Model. The present position of recently dead flat top microatoll with preserved internal structure at the eastern coast of North Andaman mainland indicates $31.21 \mathrm{~cm}$ uplift due to the 26 December, 2004 earthquake. Comparatively old cup shaped microatoll at the eastern fringe of North Andaman group of islands and highly bioeroded fossil microatolls at the intertidal zone of Little Andaman bear the signature of permanent vertical deformation in the past.
\end{abstract}

\section{Introduction}

Vertical motions related to seismic as well as aseismic tectonic processes have been widely recognized. The changes in coastal morphology, mechanical tide gauge and Global Positioning System (GPS) data as well as biological indicators like coral microatolls record this geodetic change. The coral microatolls (genera Porites and Goniastrea) act as long-term natural tide gauge because of their limited upward growth and record sea-level variations on a time-scale of decades (Zachariasen et al 1999, 2000). These can be readily used as a geodetic tool due to their widespread existence along tropical coasts across time intervals that pre-date instrumental measurements (Taylor et al 1987).

The 26 December, 2004 Sumatra-Andaman earthquake revealed a large amount of slip along the entire $\geq 1300 \mathrm{~km}$ long rupture zone (Banerjee et al 2007). This slip was associated with submergence and emergence in different parts of Andaman and Nicobar islands (Meltzner et al 2006; Rajendran et al 2007). So far, no model adequately reconciles the tsunamigenic source from the seismological data and the geodetic data (Chlieh et al 2007). Most of the models constrain horizontal motions. The vertical motion depends on the fault geometry, distribution of slip within the elastic plate, viscoelastic structure of the asthenosphere, etc. (Banerjee et al 2007) and is difficult to model. On the other hand, coral microatoll provides direct evidence of changes in elevation, because their highest level of survival can be used as a proxy for a level line and this level line has a known elevation with respect to the sea level. From the study of coral microatolls at North Reef and Interview islands on the western coast of Andaman, Kayanne et al (2007) have estimated $1.3 \mathrm{~m}$ vertical uplift in that part. Rajendran et al (2007) have shown the microatolls at Mayabandar, Middle Andaman and Landfall islands at the northernmost part of North Andaman have been uplifted at an amount of $0.69 \mathrm{~m}$ and $0.65 \mathrm{~m}$ respectively. They have also documented $0.3 \mathrm{~m}$ uplifted coral bed at Hut Bay, Little Andaman and submerged corals at Jolly Buoy, South Andaman. Bandopadhyay et al (2008) documented $0.4 \mathrm{~m}$ raised reef flat at Kalipur (North Andaman).

Keywords. Andaman; coral microatoll; geodesy. 


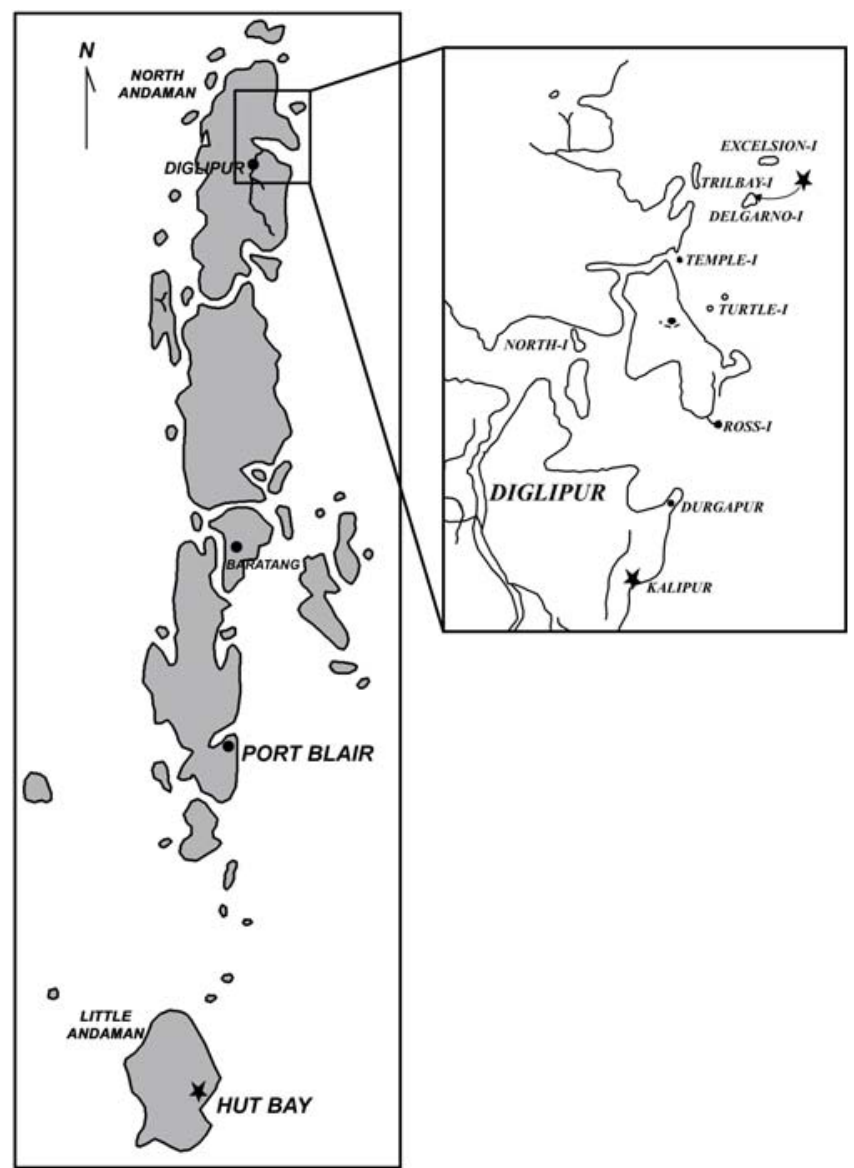

Figure 1. Location map. The areas studied are marked by $*$.

The present work is an attempt to understand the vertical uplift along limited locations in the eastern coast of North Andaman and Little Andaman (figure 1) primarily based on the external coral microatoll (Porites) morphology. We then tried to corroborate our study with published works on uplift at North Andaman islands to visualize the overall elevation change due to the combined coseismic and postsiesmic effects of 26 December, 2004 earthquake. As the field study has been carried out almost two years after the earthquake, the local information on the position of coral microatolls before and after the 2004 earthquake is given maximum weightage. All coral colonies examined and mentioned in this paper are now dead.

\section{Morphology of coral microatolls}

Coral microatoll is a single coral colony, commonly with radial symmetry, having a dead flat upper surface and a living lateral margin (Scoffin and Stoddart 1978). The growth of microatoll starts with a single polyp attached to the substrate. It grows hemispherically till it reaches the

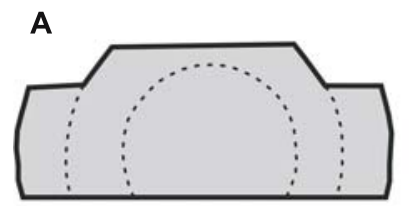

Hat Microatoll

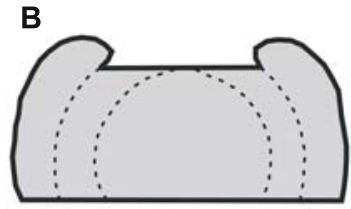

Cup Microatoll
Figure 2. External morphology of hat microatoll (A) and cup microatoll (B).

lowest low water level, above which the vertical growth ceases and the horizontal growth continues (Zachariasen et al 2000). This maximum level above which corals cannot survive and grow is known as Highest Level of Survival (HLS; Taylor et al 1987). The corals grow at a rate of few millimeters per year i.e., $1-2 \mathrm{~cm}$ per year (Knutson et al 1972; Taylor et al 1987; Priess et al 1995; Zachariasen et al 2000). Figure 2 shows the morphology of 'hat' microatoll and 'cup' microatoll used for geodetic investigations on emergence or submergence. More details on the feasibility and limitations of using microatolls as a geodetic tool are available in Scoffin and Stoddart (1978) and Zachariasen et al (2000).

\section{Results}

The microatoll study has been carried out along the eastern boundary of North Andaman and Little Andaman (figure 1). The areas include Kalipur in the east coast of North Andaman mainland and Delgarno-I island in the easternmost fringe of North Andaman group of islands. In Little Andaman, studies are concentrated mainly in Hut Bay area. All the areas were visited during December 2006-January 2007 in local low tide times.

In Kalipur area, the corals are low, between 20 and $25 \mathrm{~cm}$, with a flat microatoll plane (top dead surface). These microatolls (figure 3 ) do not show substantial rim development and lack any stepped differences in HLS surfaces. Bioerosion of the microatoll plane is minimum and the growth rims are clearly identifiable in some of the microatolls. The inset of figure 3 shows the growth rim of $\sim 1 \mathrm{~cm}$. The height to width aspect ratio is 0.17 .

The morphology of Delgarno-I microatoll differs from that of Kalipur microatoll. Finer internal structure is not observed in this microatoll. However, corals show cup morphology (figure 4) with a $3-5 \mathrm{~cm}$ raised outer rim. The height to width ratio (0.16) is nearly same with that of Kalipur microatoll. The schematic surface profile of this microatoll (figure 4) clearly differentiates two HLS surfaces with elevated $28 \mathrm{~cm}$ thick outer late HLS 


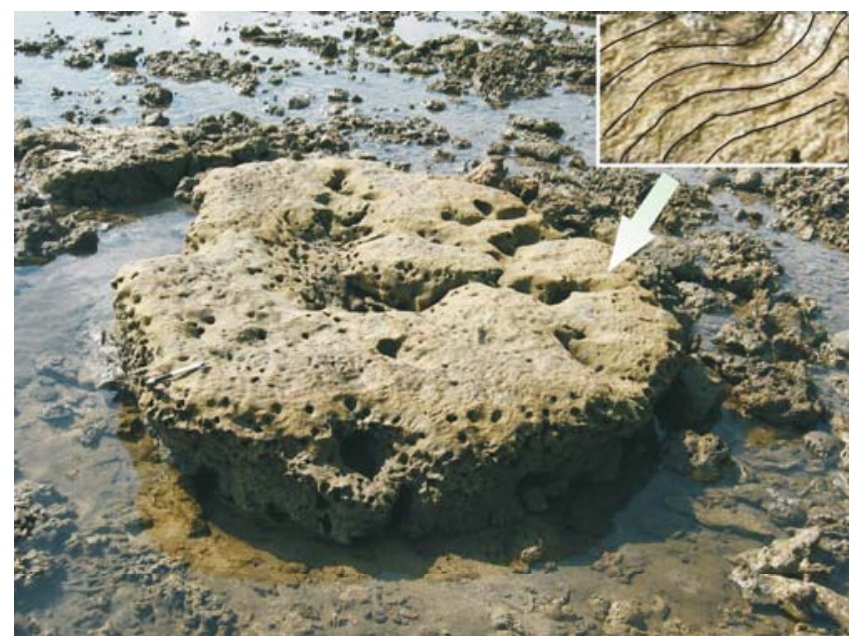

Figure 3. Coral microatoll at Kalipur area. The inset shows growth rims with thickness of about $1 \mathrm{~cm}$.

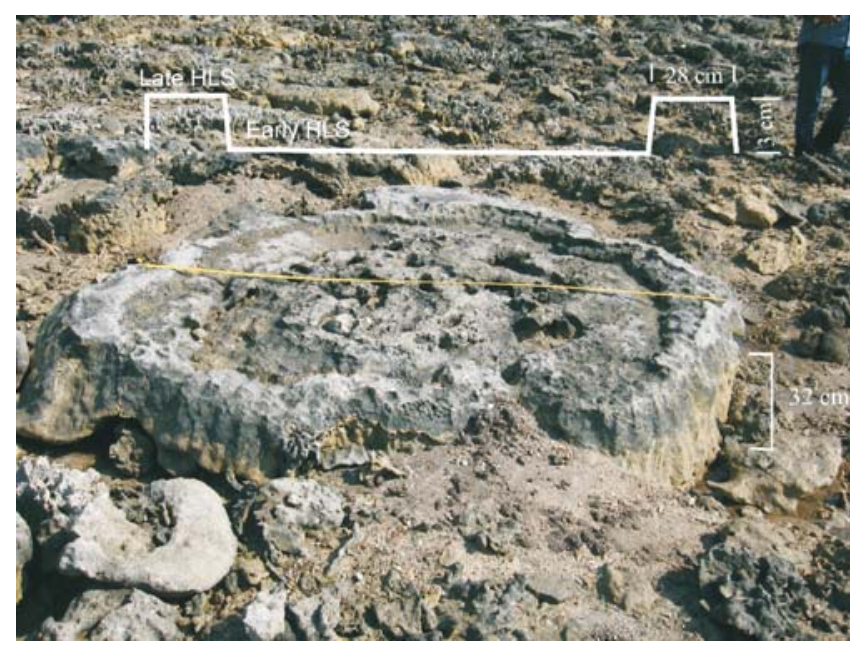

Figure 4. Coral microatoll at Delgarno island. The bar diagram shows position of early HLS and late HLS before the upliftment during December 2004 earthquake.

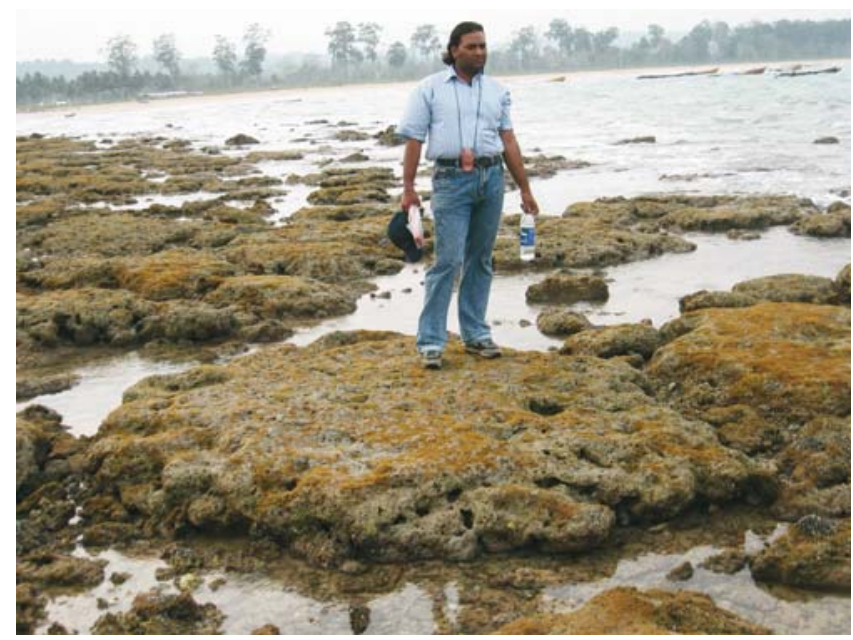

Figure 5. Moss and algae covered, highly bioeroded coral micratoll at Littile Andaman (Hut Bay). surface than the earlier one, indicating at least one episode of submergence in the area after the growth of microatoll. The earlier microatoll plane is comparatively more bioeroded than the late microatoll plane.

Query from the local people reveals that the corals examined in both these areas, were under water before the 26 December, 2004 earthquake and were brought to their present levels after this earthquake.

At Hut Bay, Little Andaman, low, wide, several meters thick coral colonies are found to form reef flat. These are highly bioeroded fossil microatoll, covered with moss and algae (figure 5) and overlain at places by $1-1.5 \mathrm{~m}$ thick beach sands.

\section{Discussion}

\subsection{North Andaman}

Living Porites microatolls have flat upper surfaces located at the low water level (Subarya et al 2006). The HLS of coral microatoll is controlled by exposure to direct sunlight (Taylor et al 1987), i.e., the day time low-low water level (LLWL) is the limiting boundary for the upward growth of microatolls. The HLS 'tracks' lowest low water levels with a sensitivity of few centimeters (Zachariasen et al 2000). The HLS for living coral microatoll at the western coast of Andaman has been estimated at $83 \pm 4 \mathrm{~cm}$ below MSL and at $24 \mathrm{~cm}$ above the lowest water level (Kayanne et al 2007). For the study areas at North Andaman, the LLWL have been calculated for December 2004 (upto 23 December) with reference to the mean sea level (MSL). The tide position and MSL were determined by NAOTIDE software using NAO.99b global ocean tide model, which gives better accuracy in shallow water coastal areas with an uncertainty of $3.083 \mathrm{~cm}$ (Matsumoto et al 2000). This LLWL with a subtraction of $24 \mathrm{~cm}$ should approximate the HLS at each site and thus considered as the reference level. These reference levels are found to be $-89.8 \mathrm{~cm}$ for Kalipur and $-91.89 \mathrm{~cm}$ for Delgarno island.

The morphology of coral microatolls from Kalipur and Delgarno islands of North Andaman recorded different HLS. The microatoll plane at Kalipur stands $\sim 20 \mathrm{~cm}$ above the low tide level on survey date. Applying the above methodology, the uplift of Kalipur is found to be $31.21 \mathrm{~cm}$ (figure 6) which matches well with the recorded uplift of North and Middle Andaman islands (Kayanne et al 2007; Rajendran et al 2007; Ray and Acharya 2007) after the 2004 earthquake (figure 7). Due to lack of data record date and level of measurement uncertainty, we have not considered the data of Bandopadhyay et al (2008) in this uplift 


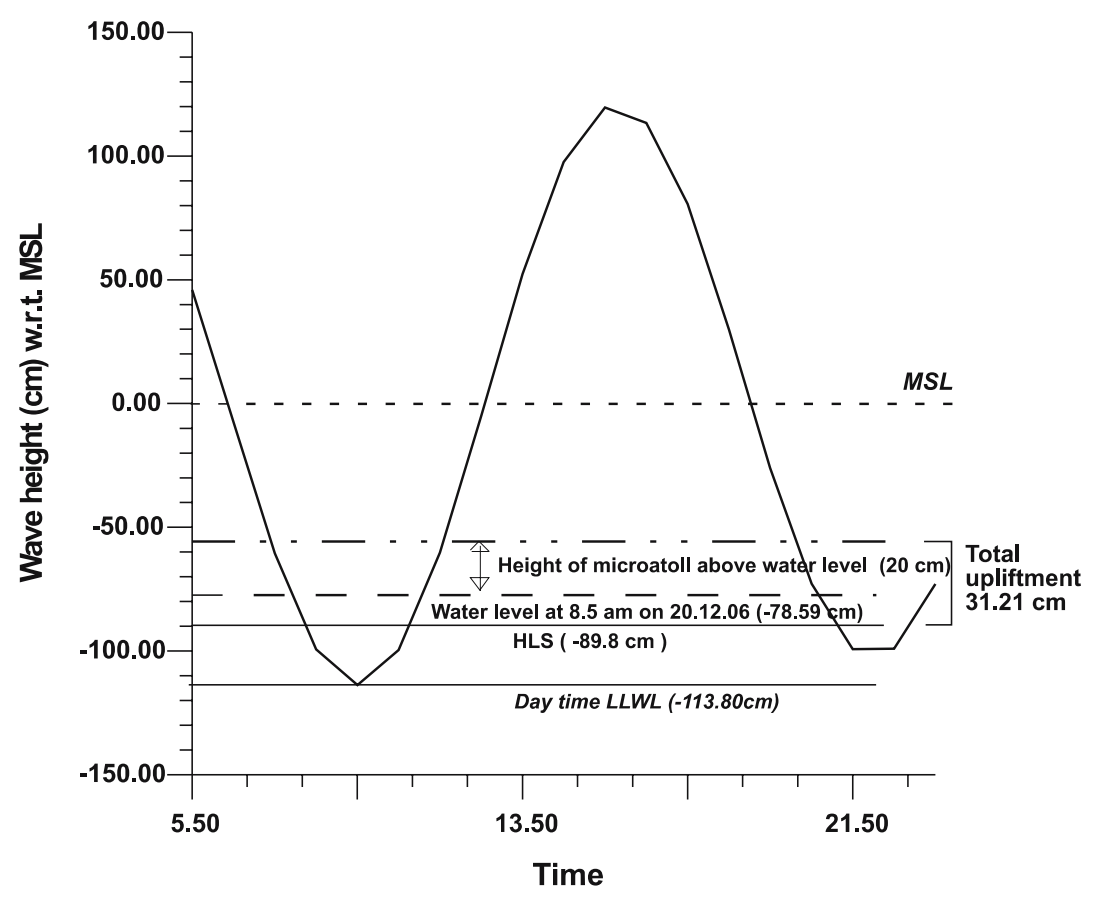

Figure 6. Diagrammatic representation of total uplift at Kalipur area by using NAO.99b model.

reconstruction. Absence of rim development at Kalipur microatoll suggests that the area was stable after the microatoll growth. However, the stepped HLS surface with cup morphology of Delgarno island microatoll suggests vertical instability. The distance of the low tide water line from the microatoll site on survey date was about $100 \mathrm{~m}$ and the beach slopes at an angle of $1^{\circ}-2^{\circ}$. Considering $1^{\circ}$ beach slope, the height difference between the low tide water line and microatoll site is $1.74 \mathrm{~m}$. The height of the microatoll is $32 \mathrm{~cm}$. With the same methodology, $2.35 \mathrm{~m}$ is the uplift of Delgarno island. Study of coastal morphology at Diglipur (North Andaman) indicates an uplift of $0.63 \mathrm{~m}$ (Rajendran et al 2007). GPS geodesy also supports this observation (Jade et al 2005). Ray and Acharya (2007) from detailed direct field observations of high water mark and emergence of rocky sea floor have estimated $20-40 \mathrm{~cm}$ vertical uplift at Kalipur area with a mean of $30 \pm 0.05 \mathrm{~cm}$ and maximum possible vertical component of slip of $6.3 \mathrm{~m}$ along the trench axis in North Andaman. The observed vertical uplift of $31.21 \mathrm{~cm}$ at Kalipur from present microatoll study corroborates these earlier field observations. The inferred $0-0.5 \mathrm{~m}$ uplift areas (Ray and Acharya 2007) includes Delgarno island which does not match with present observation. Moreover, the general trend of deformation is decreasing amount uplift from west to east. The exceptionally large amount of uplift within the small area close to Diglipur, absence of finer structures in microatoll excludes the possibility of $>2 \mathrm{~m}$ vertical uplift at Delgarno island due to
2004 earthquake, although the observed height difference definitely include a part due to the 2004 earthquake.

\subsection{Little Andaman}

At Hut Bay, Little Andaman, Rajendran et al (2007) observed $0.3 \mathrm{~m}$ uplifted coral bed. These coral beds comprise of microatoll and other coral colonies, which are highly bioeroded and covered with moss and algae. This vegetation will not grow in living coral but will grow in the intertidal zone on coral heads that have been exposed and dried (Meltzner et al 2006). From the degree of bioerosion and algal growth, it is quite possible that the observed coral bed uplifted on this site due to 2004 earthquake, when these are already dead. However, both the coral colonies present at Delgarno island and Hut Bay, Little Andaman bear the signature of palaeo-seismicity.

This preliminary observation suggests the potentiality of coral microatolls as a geodetic tool to understand the vertical ground movements. Although there are sampling restrictions (Rajendran et al 2007), more detailed work on coral microatoll is warranted in the Andaman region for precise palaeogeodetic reconstruction and to understand the earthquake recurrence.

\section{Acknowledgements}

This work was carried out during post-seismic GPS monitoring of Andaman region. The authors are 


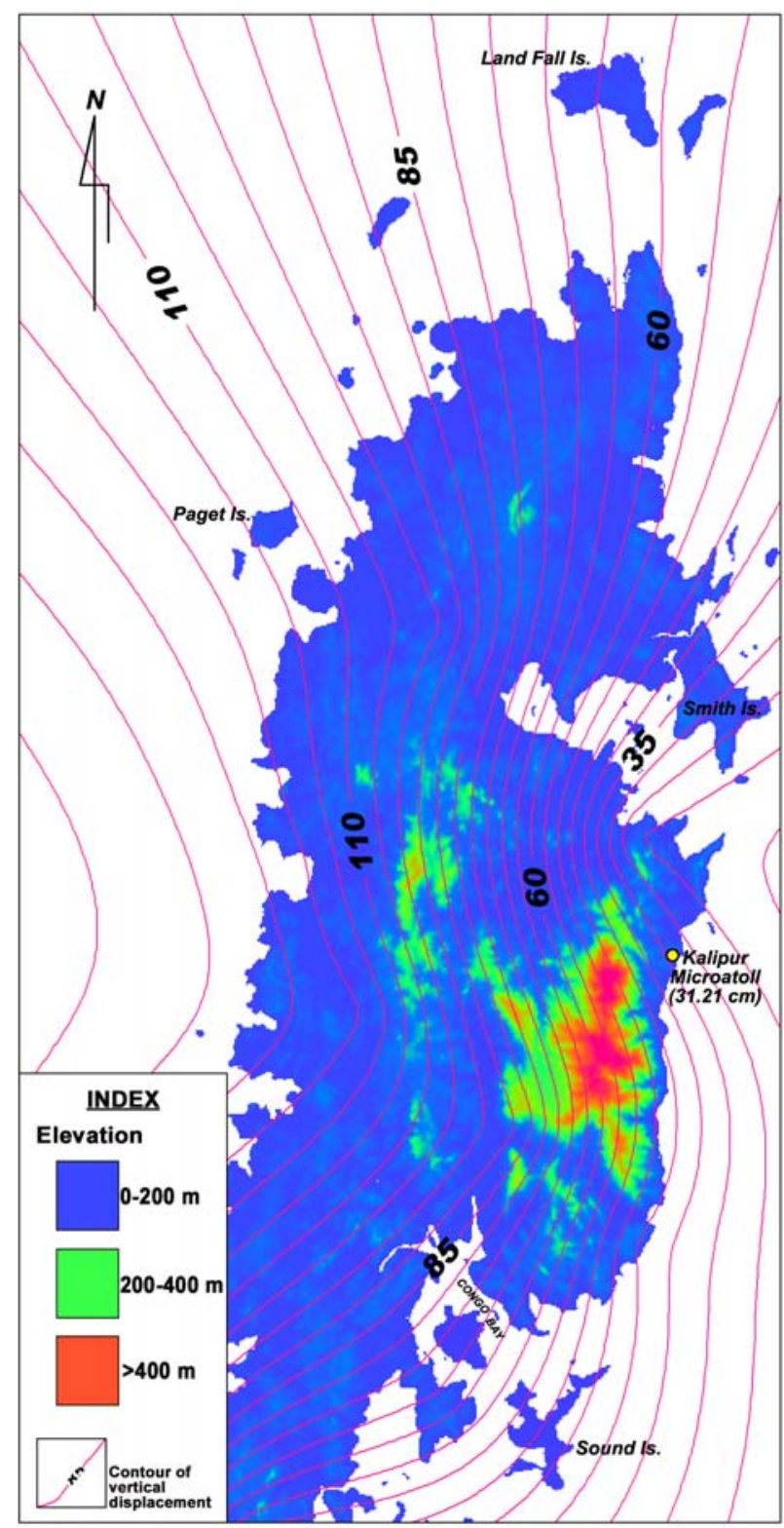

Figure 7. Combined static vertical displacement at North and Middle Andaman after (Kayanne et al 2007; Rajendran et al 2007; Ray and Acharya 2007) showing the matching displacement recorded from microatoll at Kalipur. The base map is SRTM image showing elevations.

grateful to the Deputy Director General, Eastern Region, Geological Survey of India for giving the permission to publish the work. They are also indebted to the Divisional Forest Officer, North Andaman for assisting in the cruise to Delgarno island. The authors express their gratitude to two anonymous reviewers and Malay Mukul, the Associate Editor for their comments and suggestions which greatly helped to improve the manuscript.

\section{References}

Bandopadhyay P C, Chakraborty U, Mohapatra N R and Roy A 2008 New field evidence of coseismic coastal uplift during the December 2004 earthquake, North Andaman island; J. Geol. Soc. India 71 871-874.

Banerjee P, Pollitz F, Nagarajan B and Bürgmann R 2007 Coseismic slip distributions of the 26 December 2004 Sumatra-Andaman and 28 March 2005 Nias earthquake from GPS static offsets; Bull. Seismol. Soc. Am. 97(1a) S1-S17.

Jade S, Ananda M B, Dileep Kumar P and Banerjee S 2005 Coseismic and postseismic displacements in Andaman and Nicobar islands from GPS measurements; Curr. Sci. 88(12) 1980-1984.

Kayanne H, Ikeda Y, Echigo T, Shishikura M, Kamataki T, Satake K, Malik J N, Basir S R, Chakrabortty G K and Ghosh Roy A K 2007 Coseismic and postseismic creep in the Andaman Islands associated with the 2004 SumatraAndaman earthquake; Geophys. Res. Lett. 34 L01301, doi:10.1029/2006GL028200.

Knutson D W, Buddemeier R W and Smith S V 1972 Coral chronometers: Seasonal growth bands in reef corals; Science 177 270-272.

Matsumoto K, Takanezawa T and Ooe M 2000 Ocean tide models developed by assimilating TOPEX/POSEIDON altimeter data into hydrodynamical model: A global model and a regional model around Japan; J. Oceanogr. 56 567-581.

Meltzner A J, Sieh K, Abrams M, Agnew D C, Hudnut K W, Avouac J P and Natawidjaja D H 2006 Uplift and subsidence associated with the great Aceh-Andaman earthquake of 2004; J. Geophys. Res. 111 B02407, doi:10.1029/2005JB003891.

Priess K, Thomassin B A, Heiss G A, Dullo W C and Camoin G 1995 Variabilite de la croissance de Porites massifs dans les recifs corallines de Mayotte; C.R. Acadamy of Science, Paris, Sciences de la vie $\mathbf{3 1 8}$ $1147-1154$.

Rajendran C P, Rajendran K, Anu R, Earnest A, Machado T, Mohan P M and Freymuller J 2007 Crustal deformation and seismic history associated with the 2004 Indian Ocean earthquake: A perspective from the Andaman-Nicobar Islands; Bull. Seismol. Soc. Am. 97(1a) S174-S191.

Ray S K and Acharya A 200726 December 2004 earthquake: Coseismic vertical ground movements in the Andaman; Geol. Surv. India Spec. Publ. 89 63-81.

Scoffin T P and Stoddart D R 1978 The nature and significance of microatolls; Phil. Trans. Roy. Soc. London B 284 99-122.

Northern California Earthquake Data Centre, www@ncedc.org, 2006.

Subarya C, Chlieh M, Prawirodirdjo L, Avouac P, Bock Y, Sieh K, Meltzner A J, Natawidjaja D H and McCaffrey R 2006 Plate boundary deformation associated with the great Sumatra-Andaman earthquake; Nature $\mathbf{4 4 0}$ 46-51.

Taylor F W, Frohlich C, Lecolle J and Strecker M 1987 Analysis of partially emerged corals and reef terraces in the Central Vanuatu Arc: Comparison of contemporary coseismic and nonseismic with quaternary vertical movements; J. Geophys. Res. 92 4905-4933. 
Zachariasen J, Sieh K, Edwards R L, Taylor F W and Hantoro W S 1999 Pre- and coseismic vertical displacement associated with the giant 1833 Sumatran subduction earthquake, evidence from coral microatolls; J. Geophys. Res. 104 895-919.
Zachariasen J, Sieh K, Taylor F W and Hantoro W S 2000 Modern vertical deformation above the Sumatran subduction zone: Paleogeodetic insights from coral microatolls; Bull. Seismol. Soc. Am. 90 897-913.

MS received 10 June 2008; revised 31 October 2008; accepted 16 January 2009 